\title{
Articles
}

PIOTR SZAJNER

DOI: $10.30858 /$ zer/84966

Institute of Agricultural and Food Economics

- National Research Institute

Warsaw

\section{PRICE TRANSMISSION ON MILK MARKET IN POLAND BETWEEN 2004 AND 2017}

\begin{abstract}
The Polish dairy industry adjusted to the conditions of membership in the EU where the milk market is among the most regulated food markets. Despite elaborated market regulations, prices of raw milk and milk products in Poland were characterised by major variability. This in particular concerns buying-in and selling prices. There is a surplus of supply on the milk market which is exported. Therefore, the price situation in the country is strongly dependent on the economic situation on world markets. Buying-in and selling prices show similar directions of changes as world prices. Price variability has also been noted in the national marketing chain because prices on its respective stages are characterised by a very considerable dynamics. The price transmission process in the national supply chain of dairy products shows major asymmetry. Thus, what is justified are market policy instruments which limit risk to running economic activity and strengthen the position of farmers in relations with dairy industry and retail trade.
\end{abstract}

Keywords: dairy industry, prices, market, marketing chain, price transmission.

JEL codes: D40, D20, C10. 


\section{Introduction}

The market is a crucial category in the economics, but despite the wide interest of economic sciences in this issue, in the literature of the subject there is no widely used and accepted definition of the market. In a general sense, the market is defined as all relationships taking place among entities involved in the processes of trade. Market entities are primarily sellers and buyers, who represent, respectively, the sphere of supply and demand. Particularly important are the interrelationships between supply and demand (Wrzosek, 2002). In this context, the market reflects the relationships between the decisions of buyers and sellers which are mutually agreed through prices, which is a specific market mechanism (Rembisz and Kowalski, 2007). In the economic literature, the market often is also a synonym for categories such as the sector and industry (Pietrzak, 2014).

From the definitions quoted, we can specify three basic elements of the market: supply, demand and prices. The prices are a resulting element which also governs the relationships between the demand and supply. Therefore, the price mechanism illustrates the relationships between the demand and supply side of the market. The market is said to perform four basic functions: balancing, information, profit-making and efficiency. The balancing function of the market is a feature and ability to automatically restore the balance between supply and demand. Depending on the structure and spatial range of the market, the balance is affected by many different factors which stabilise or destabilise the whole system (e.g. intervention policy, international relations). The market also provides many up-to-date and historical information that can be used by entities in making economic and political decisions. Market participants, relying on the information and signals, pursue a specific economic activity (market game), which provides an opportunity to increase income. Economic success in the market is achieved mainly by efficient and competitive entities. In this context, the market verifies efficiency. The market mechanism also stimulates the efficient allocation of factors (labour and capital). In all these functions of the market, a very important role is played by prices. The market balance is restored through the price mechanism. Prices at the individual stages of the marketing chain (supplies) are a basis for the market information and analysis. Prices also play an important role in creating income of market participants and in assessing the efficiency of pursuing the economic activity as well as of the market mechanism itself. In the economic literature, there are the views challenging the market efficiency in determining prices and the inefficiency of the market mechanism is indicated as a justification for the protectionist market policy, the result of which is an extensive system of regulations (Hamulczuk, 2013).

Markets can be analysed in the subject, spatial and object context. Market entities are participants representing the supply side (producers, sellers) and consumers (buyers) on the demand side. An important element of the market analysis by subjects is its structure, which mostly can be understood as the level of 
concentration (e.g. monopoly, oligopoly, etc.). On markets subject to the system of regulations, administration units are also market entities. By objects, we may identify the market of products, services, labour and money (Wrzosek, 2002). Market analyses in the spatial context are based mainly on the range of the market impact: local, national, regional, world (global) (Mynarski, 1993; Pietrzak, 2014). In recent years, the regional integration and globalisation processes have been consolidatied and, as a result, domestic markets become elements of the global market (Szymański, 2002). The economic situation in external markets can have a great impact on the supply-demand or price situation on local markets. In particular, this applies to industries which have the intense economic relations with foreign countries.

Price analyses are one of the basic elements of market research and this is determined by theoretical and utilitarian considerations. In the theory of economics, two main trends stressing the efficiency and inefficiency of the market mechanism tend to clash (Varian, 1997; Samuelson and Nordhaus, 2004). Market research, including in particular price analyses, may explain price volatility deviating from the trends and dependencies identified in the theory of economics. Therefore, the results of analyses may verify the assumptions of the theory of the market or contribute to the deliberations and formulation of new theoretical dependencies. Price research is also of practical significance, as it provides producers, consumers and administrations with detailed and up-to-date information. On this basis, market entities can make decisions, and scientific institutions can assess the efficiency of the market mechanism and regulatory instruments (Rembeza and Seremak-Bulge, 2010).

The milk market in Poland in the period of economic transformation and the EU membership has undergone very deep changes adapting it to the everchanging political and economic conditions, which included both structural, ownership and modernisation changes. The literature of the subject mentions the following stages of these processes: transformation into the market economy, liberalisation of foreign trade as part of GATT/WTO, the preparation for accession to the EU, implementation and further reforms of the Common Agricultural Policy (Seremak-Bulge, Szajner, Świetlik, Hryszko, Rembeza and Pieniążek, 2005; Urban, 2008; Sznajder, 1999). Ownership changes and concentration of subject structures had a significant impact on the price mechanism in the entire marketing chain. The objective of the article is to assess price volatility on the Polish and global milk and dairy products market and at the individual stages of the national marketing chain, with a particular emphasis on the price transmission process.

\section{Theoretical aspects of price volatility and price transmission}

Prices are the most dynamic part of the market, and the issue of price volatility and transmission has always been a subject of theoretical considerations 
and empirical market analyses. Of interest to researchers and market analysts is the price transmission mechanism (the so-called price formations process) both within the specified marketing chain (supplies), and among the markets separated in space. The basis for theoretical considerations, was the law of one price and perfect competition models built on its basis which assume proportionate (symmetric) reactions of the price mechanism in horizontally related markets and within the vertically related stages of the supply chain (Takayama and Judge, 1971). These theoretical considerations are also a basis for the assumptions and analyses of market cointegration. The concept assumes that there may be short-term disruptions among prices of compared products, however, in the long term the balance is maintained. If among analysed prices there is cointegration, such markets can be defined as cointegrated (Engle and Granger, 1987; Granger and Lee, 1989; Aczel, 2005; Hamulczuk, 2013). In the economic realities, the assumption on proportional (equivalent) price reactions in the related markets and within the marketing chain is very often infringed. This is determined by the fact that many markets (industries) function in conditions deviating from the assumption on perfect competition (Pelzmann, 2000). Reactions and price signals take place with some delay or in advance and the scale of price rises and falls is diversified.

The issue of price mechanism and price transmission on agri-food markets has been the subject of numerous scientific studies for many years. The results of these studies showed that price processes are subject to many disruptions and one of their symptoms is asymmetric price transmission both in horizontal and vertical terms (Ward, 1982; Ball and Mankiw, 1994; Aguiar and Santana, 2002; Conforti, 2004; Holst and von Cramon-Taubadel, 2012). The subject of scientific studies and analyses was also price volatility and price transmission in the milk and dairy products market. The results of the conducted analyses showed that prices on markets separated in space and at the stages of the marketing chain in Poland had been characterised by the diverse growth rate and the price transmission process was asymmetric (Chavas and Metha, 2004; Rembeza and Seremak-Bulge, 2009; Rembeza and Seremak-Bulge, 2010; Szajner, 2015). Confirmation of disruptions and asymmetry of the price transmission process on food markets, including the milk market, is of theoretical and utilitarian importance. At the theoretical level, the results of these studies clearly show that the classical theory of economics does not take into account all detailed aspects of price volatility. Empirical studies and testing price transmission are important for market participants. Economic entities can better prepare their market (marketing) strategies for ever-changing conditions, and administration may prepare more effective market policy instruments (the so-called safety net).

An important element of the studies in the field of asymmetric price transmission is not only to conclude on its occurrence and measure the scale of disruptions but also to identify the determinants. The literature, as the basic factors 
determining price transmission disruptions, mentions imperfect competition and the degree of organisation of market participants. This is particularly visible in such forms of imperfect competition as monopolies and oligopolies, and also on markets with the significantly more fragmented subject structure. Market participants with the stronger market position can interfere with the price transmission process. In particular, asymmetric reactions of these participants exist in conditions of price decline trends (McCorriston, Morgan and Rayner, 2001). In the agri-food sector, the market position of the food industry and retail chains is stronger than that of farmers and consumers, who are less organised and integrated. Another element distorting price transmission are price expectations of market participants. The literature presents the principle that price signals are transmitted more strongly and faster if market participants are convinced of consolidation of price rise trends. In weaker economic situation, market entities, which are characterised by prudent decisions, are less willing to take risk (Von Cramon-Taubadel, 1998). Distortions of the price process may also result from the intervention policy, which also affects the market efficiency and participants' management efficiency (Ward, 1982; Rembisz and Kowalski, 2007). In the food market, the asymmetric price transmission may also result from the product's characteristics and properties. In the case of short-shelf life products (e.g. milk, yoghurt and kefir, cottage cheese), retail trade shows a smaller tendency to rise prices in response to the dynamic growth of prices in agriculture and processing. Also, however, in the conditions of deep falls of purchase and selling price, prices in retail trade generally are less dynamic. The above problems have been noticed in the EU and market policy instruments are aimed at strengthening the position of the farmers and the food industry in the marketing chain (e.g. written contracting agreements, producer and interbranch organisations) (Regulation No. 1308/2013).

Distortions in price volatility and transmission can be presented graphically using the concept of welfare, which is one of the fundamental objectives of the economic activity (Samuelson and Nordhaus, 2004). Welfare may be simply defined as the total of surplus of consumers $\alpha$ and producers $\beta$, which is then reduced by the specific loss $\gamma$ (Łyszkiewicz, 2000). Price transmission in the supply chain affects the marginal costs of production and distribution of goods $c$ and their selling prices $p_{0}$ and the surplus of consumers and producers, and, consequently, the losses of welfare. The impact of price transmission on welfare can be illustrated using the inverse demand function $P=f(Q)$. If product prices are significantly higher than costs, then the surplus of producers increases while the surplus of consumers decreases. The effect of such relations is the growing loss on welfare. The smallest losses of welfare take place when companies sell products at prices close to marginal costs (Fig. 1).

In the agri-food sector, a simplified marketing chain can be defined as follows: production of raw materials in agriculture, food processing and distribu- 
tion (e.g. retail trade). In the economic realities, the flow of goods is much more complicated, as an important role is played by foreign trade, direct sales of products without industrial processing and retail trade. It should also be remembered that in the food sector there is big internal turnover, including, in particular, among food industry establishments, but also in agriculture. An important role is also played by the market policy: intervention purchases, support for demand and promotional measures. By adopting a simplified model of the marketing chain at its individual stages, we can identify the following price categories: purchase prices of agricultural products, selling price in the food industry and retail prices of food products.

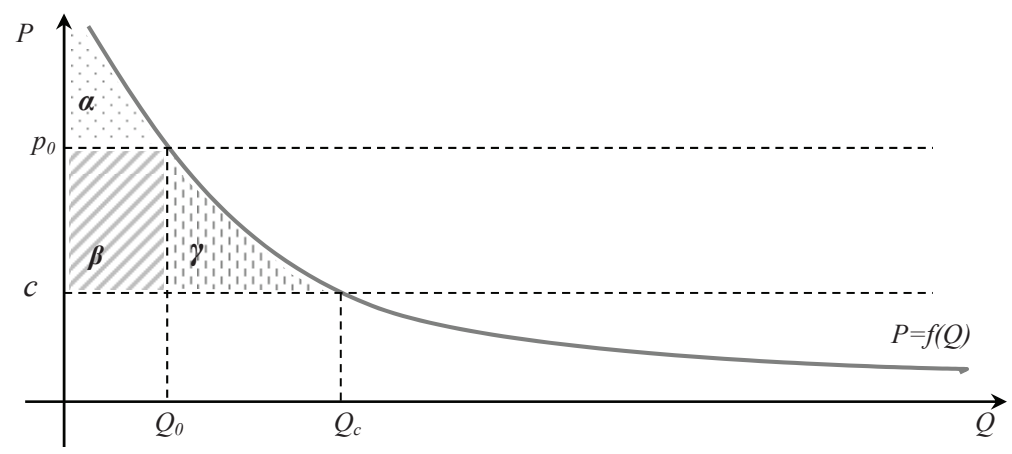

Fig. 1. Prices, costs and welfare.

Source: own study according to Łyszkiewicz (2000, p. 49).

Price volatility and transmission can be analysed using numerous statistical and econometric methods based on time series (stochastic processes). The analysis should be based on an assessment of the growth rate prices in real and nominal terms at the individual stages of the supply chain. On this basis, we can show the differences in the volatility of the individual price categories. At the next stage, necessary is a detailed analysis of time series. Decomposition of the stochastic process into components (long-term trend, cyclical fluctuations, seasonal fluctuations and random fluctuations) will allow us to identify the main determinants of price volatility. Decomposition of time series of prices can be performed using the X-12 ARIMA method (Hamulczuk, 2011). Analysis of price transmission is also an assessment of causal relationships in the marketing chain, which uses the concept of the long-term balance among prices (the so-called cointegration) (Engle and Granger, 1987; Kusideł, 2000). In short periods, there are imbalances, but the market is characterised by a capacity to restore it by means of prices (Rembisz and Smith, 2007). The concept of cointegration analysis in the sense of Engle-Granger in the case of non-stationarity of time series requires bringing 
them to the stationary form. In the case of asymmetric price transmission, causal models lose their strength (Ball and Mankiw, 1994; Azzam, 1999). Inclusion of asymmetry is allowed by the modification of the Engle-Granger model which involves introducing into the model instead of one exogenous variable, two variables separately representing price rises and falls (Houk, 1977).

\section{Study method and empirical data}

Analysis of price volatility on the Polish market in milk and dairy products used accumulated indicators of monthly raw milk purchase prices, prices of the marketed production of the dairy industry (selling prices) and retail prices of dairy products. The existing studies of price volatility and price transmission processes concerned raw milk and detail prices of specific dairy products (Rembeza and Seremak-Bulge, 2009; Holm, Steinhagen and Loy, 2010). The results of those studies showed that distortions of the price transmission of individual products were highly diversified and, on this basis, it was difficult to formulate general conclusions for the entire dairy industry. The use of aggregated price indices at the individual stages of the marketing chain: agriculture, dairy industry and retail trade makes it possible to generalise the conclusions and assess the situation on the milk market.

The milk market in Poland is strongly associated with the EU and world markets, as foreign trade turnover has a large share in the market balance and turnover of the dairy industry. Therefore, in order to illustrate the impact of the economic situation on the external markets on the domestic market, analysis covered the volatility of global prices of dairy products (FAO Price...) and indicators of milk purchase prices and sale of the marketed production of the dairy industry.

Analysis of asymmetric price transmission in the Polish dairy industry was carried out using the Error Correction Mechanism. If two time series are cointegrated at the first level I(1), then the error correction parameter $\alpha E C T$ presents regaining the long-term balance (1-2). Asymmetry occurs when the coefficients $\alpha+E T C+$ and $\alpha-E T C$ - differ significantly. Non-stationary time series regain their balance, if the parameter values are $-1 \leq \alpha \leq 0$. The parameters $\beta$ in the model indicate short-term adjustments to the balance. Stationarity of time series and cointegration were tested using the Dickey-Fuller test for a unit root (ADF), in which the hypothesis $\mathrm{HO}$ assumes non-stationarity of a series.

$$
\begin{gathered}
\Delta P_{t}^{e n}=c+\gamma \Delta P_{t}^{e x}+a E C T_{t-1}+\sum_{i=1}^{L} \beta_{i} \Delta P_{t-1}^{e n}+\sum_{i=1}^{L} \beta_{j} \Delta P_{t-1}^{e x}+\varepsilon_{t} \\
\Delta P_{t}^{e n}=c+\gamma_{1}^{+} \Delta P_{t}^{e x^{+}}+\gamma_{1}^{-} \Delta P_{t}^{e x^{-}}+a^{+} E C T_{t-1}^{+}+a^{-} E C T_{t-1}^{-}+\sum_{i=1}^{L} \beta_{j} \Delta P_{t-1}^{e x}+\varepsilon_{t}
\end{gathered}
$$


where:

$\Delta P_{t}^{e n} \quad-$ endogenous variable,

$\Delta P_{t}^{e x} \quad-$ exogenous variable,

$\beta_{i}, \beta_{j} \quad-$ lag polynomials,

$E C T^{+}, E C T^{-}$- error correction parameters of price falls and rises,

$\gamma$

- parameter of matching the endogenous variable to changes in the exogenous variable,

c - constant.

In the analysis of asymmetric price transmission in the Polish milk market, unpublished CSO statistical data was used, including monthly indices of purchase, selling and retail prices. Static analysis was carried out using the Gretl statistical and econometric package.

\section{Evolution of the milk market in Poland after the accession to the European Union}

The Polish dairy industry in the pre-accession period was subject to very deep transformations, adapting it to the EU integration (Urban, 2004; SeremakBulge, 2009). The accession to the EU in 2004 and inclusion of the domestic dairy industry into the common market resulted in a fundamental change in the market conditions of the dairy industry, which was covered by the single system of regulations (Regulation No. 1787/2003). Farms and the dairy industry were granted access to the huge outlet market, characterised by the large purchasing power of consumers (Gross National Income...). A prerequisite was to carry out deep adaptation processes, which applied both to the system market organisation (administration), as well as adjustments to the standards in the field of food (veterinary and hygiene ${ }^{1}$ ) and agri-environmental regulations.

The basis for the EU system of market regulations was the administrative limitation of supply limiting (the so-called milk quotas), complemented by many other market policy instruments: intervention (purchases of butter and milk powder), support for the internal demand (e.g. School Milk Scheme, consumption of milk powder for fodder purposes, etc.), foreign trade regulations,

\footnotetext{
${ }^{1}$ Until 1 January 2006, the regulations on the veterinary standards in the milk production in the EU were governed by Directive 92/46/EEC of 16 June 1992, layning down the health rules for the production and placing on the market of raw milk, heat-treated milk and milk-based products. In the next period, the hygiene requirements in the EU have been extended under the Regulation (EC) No. 852/2004 of the European Parliament and of the Council of 29 April 2004 on the hygiene of foodstuffs (L 139, 30.04.2004); Regulation (EC) No. 853/2004 of the European Parliament and of the Council of 29 April 2004 laying down specific hygiene rules for food of animal origin (L 139, 30.04.2004); Regulation (EC) No. 854/2004 of the European Parliament and of the Council of 29 April 2004 laying down specific rules for the organisation of official controls on products of animal origin intended for human consumption (L 155, 30.04.2004).
} 
support for investments on farms and dairy industry and direct support for farmers' incomes. Integration with the EU coincided with the reform of the regulations in 2003, and then with changes under the Health Check in 2008. In April 2015, the milk quotas were abolished and the market regulations interfere far less with the laws of the market.

In 2004-2016, the dairy industry was subject to deep restructuring and modernisation. Structural transformations applied to all stages of the marketing chain, which consisted primarily in the process of concentration of structures, and consequently in increasing economies of scale. The number of farms selling milk to the dairy industry decreased by $62 \%$ to about 125 thousand. At the same time, the average sales volume of milk from the farm increased almost fourfold to 89 tonnes per year. In the same period, the number of enterprises employing more than 9 employees decreased by about $30 \%$ to 175 , and the average processing rate of the raw material increased nearly twice to 63 thousand tonnes. In the milk production, the processes of concentration were more intense than in the dairy industry. During the period of the EU membership there have been no major ownership changes in milk processing, understood as the process of privatisation and foreign direct investment. The dairy industry is still dominated by the cooperative forms of ownership and this is the only industry where agriculture is so strongly integrated with the processing industry. There were, however, very clear tendencies to consolidation of dairy cooperatives into larger operators. Structural transformations of the industry have not been completed yet. The Polish dairy industry, despite a clear increase in concentration, is still characterised by fragmented subjective structures when compared to the main competitors from the EU-15 (Pietrzak, 2006; Szajner, 2009), as well as in relation to large retail chains. Fragmented object structures have a negative impact on the economies of scale and efficiency of management and they undermine the position in the marketing chain.

The increase in concentration of the milk production and processing is visible at the regional level as well, because a group of voivodships specialised in the milk production was developed (Seremak-Bulge, Hryszko and Zalewski, 2006). In 2015, in seven voivodships: Kujawsko-Pomorskie, Lubelskie, Łódzkie, Mazowieckie, Podlaskie, Warmińsko-Mazurskie and Wielkopolskie, purchase of raw milk was about 9 million tonnes in total, which accounted for $86 \%$ of milk supplies of the dairy industry in Poland (GUS, 2016).

The processes of the growth in concentration of the milk production and processing were accompanied by large investment inputs, whose effect was the improved technical and economic efficiency. In 2004-2016, the population of cows in Poland decreased by about $17 \%$ to 2.3 million heads. The decrease in the number of cows was compensated by an increase in the average milk yield by $48 \%$ to $6,220 \mathrm{~kg}$ and, consequently, the milk production increased by $12 \%$ to 13.2 million tonnes (Table 1). The increasing production was accompanied 
by major changes in the structure of its distribution. Supplies to the dairy industry increased by $39 \%$ to 11.1 million tonnes and are about $84 \%$ of the milk production (the so-called marketability of the production). In the EU-15 countries, being large raw milk producers and also the main competitors, the dairy industry processes $97 \%$ of the output. In Poland, large quantities of milk are still consumed on farms (self-supply and feed) and the great role is played by direct sale of milk and dairy products (Rynek mleka..., 2017).

The demand on the domestic market shows an upward trend, but its growth rate was lower than that of the supply. As a result, there is excessive supply on the market, which when measured by the self-sufficiency indexes ${ }^{2}$ is about $118 \%$. The demand for dairy products on the internal market still remains insatiable and there are opportunities for its growth, as well as changes in the structure of consumption (e.g. greater consumption of cheese and curd, butter). The consumption of milk and dairy products in Poland is still lower than in the EU-15 countries (AMI, 2017).

The supply surpluses are sold on the internal market, mainly in the EU, which is the main outlet market of domestic dairy products. The Polish dairy sector is competitive on the external markets (Szajner, 2009). Competitive advantages are mainly of price-cost nature while maintaining very high quality standards. In the analysed period, the export of dairy products expressed in raw material equivalent increased by $85 \%$ to 3.8 million tonnes. The export is of great importance, since it accounts for about $32 \%$ of purchase and about $27 \%$ of revenues from the sale of the dairy industry. The import increased to a greater extent to 1.8 million tonnes and its share in the supply to $16 \%$. Foreign trade is characterised by the increasing intensity of intra-industry trade in raw milk equivalent and in value terms, which is typical in the EU-15 countries (Czarny, 2002). An important role in this respect is played by the import of liquid milk and cream, including condensed milk, which is then processed in national establishments. The Polish dairy industry has surpluses of the processing capacity in relation to purchase (Pietrzak, 2006). Therefore, companies are looking for raw material also abroad (e.g. Lithuania, the Czech Republic). The processing import helps make better use of the production factors' resources and benefit from value added.

\footnotetext{
${ }^{2}$ The self-sufficiency index is counted as a ratio of the raw milk production to its consumption, i.e. production less the balance of foreign trade in raw material equivalent. An assumption on permanent stocks was also made as on the domestic dairy products market there are relatively low stocks of durable dairy products: butter, milk powder and hard cheese.
} 
Table 1

Trends in the production, processing and foreign trade of the Polish dairy industry

\begin{tabular}{|c|c|c|c|c|}
\hline Specification & Unit & 2004 & 2016 & $2004=100 \%$ \\
\hline \multicolumn{5}{|c|}{ Production of raw milk in agriculture } \\
\hline Population of cows & thousand heads & 2,777 & 2,303 & 82.9 \\
\hline Milk yield & $\mathrm{kg}$ & 4,205 & 6,220 & 147.9 \\
\hline Production & thousand tonnes & 11,822 & 13,244 & 112.0 \\
\hline Purchase & thousand tonnes & 8,002 & 11,135 & 139.2 \\
\hline Share of purchase inproduction & $\%$ & 67.7 & 84.1 & - \\
\hline Number of suppliers & thousand & 330 & 125 & 37.9 \\
\hline Size of average supply & tonnes & 24 & 89 & 371.2 \\
\hline \multicolumn{5}{|c|}{ Milk processing in the dairy industry } \\
\hline Number of enterprises & & 245 & 175 & 71.4 \\
\hline $\begin{array}{l}\text { Average amount of milk } \\
\text { processed per company }\end{array}$ & thousand tonnes & 33 & 64 & 193.9 \\
\hline Production of milk articles: & thousand tonnes & & & - \\
\hline processed liquid milk & thousand tonnes & 2,082 & 3,350 & 160.9 \\
\hline milk powder & thousand tonnes & 172 & 200 & 116.3 \\
\hline cheese & thousand tonnes & 296 & 450 & 152.0 \\
\hline ripened cheese & thousand tonnes & 219 & 327 & 149.3 \\
\hline butter & thousand tonnes & 178 & 204 & 114.6 \\
\hline yoghurt and drinks & thousand tonnes & 469 & 703 & 149.9 \\
\hline \multicolumn{5}{|c|}{ Foreign trade in dairy products } \\
\hline Export in raw material equivalent & thousand tonnes & 2050 & 3810 & 185.0 \\
\hline Import in raw material equivalent & thousand tonnes & 235 & 1,793 & 736.0 \\
\hline Balance in raw material equivalent & thousand tonnes & 1,575 & 2,017 & 128.1 \\
\hline Share of export in purchase & $\%$ & 22.6 & 32.4 & - \\
\hline Share of import in market supply & $\%$ & 2.3 & 16.0 & - \\
\hline \multicolumn{5}{|c|}{ Milk consumption and self-sufficiency } \\
\hline Use & thousand tonnes & 10,007 & 11,227 & 112.2 \\
\hline Self-sufficiency & $\%$ & 118.1 & 118.0 & - \\
\hline
\end{tabular}

Source: own calculations, data from GUS, ARR, MF CAAC. 


\section{Price volatility and transmission on the market of milk and dairy products after the accession to the European Union}

The consequence of intensive trade with foreign countries in the dairy industry is a strong link with the external markets, which is visible in price trends. Price changes in the global market are transmitted (transferred) to prices in the domestic market. Statistical and econometric analysis showed that in 2004-2016 the trends of changes in global and national prices were similar, despite the significant differences in the methodologies for measuring their dynamics. The synthetic indicator of the assessment of price volatility and the economic situation in the global market of dairy products is the FAO Dairy Price Index (FAO Price...), which illustrates the dynamics of prices in relation to the average values of the baseline period 2002-2004. Therefore, this index is more real than indices of purchase and selling prices showing their dynamics when compared to the previous year. Therefore, price indices on the domestic market are nominal.

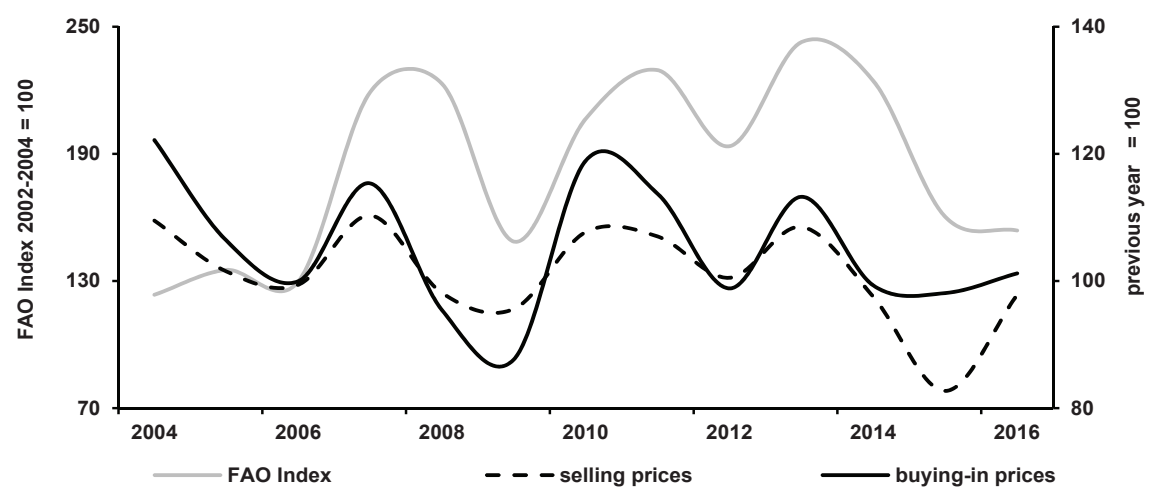

Fig. 2. Dynamics of prices in the global and domestic milk market.

Source: own study based on GUS unpublished data, FAO Food Price Index.

Regardless of the methodological differences, statistical analysis confirmed not only the integration of the domestic market with the global market, but also very similar periodical fluctuations. The characteristic feature of changes taking place in the economy, both in macro- and microeconomic terms, is the periodicity defined in the literature as the business cycle. In the business cycle, there are four basic phases: crisis, depression (stagnation), recovery and growth (boom). The crisis phase is characterised by the predominance of supply over efficient demand, consequently prices show a downward trend and the economic activity deteriorates. The depression phase is characterised by the stabilisation of the economic activity, but at a very low level. After a certain period, the economy reaches the so-called lower turning point and the recovery phase begins. Prices and economic activity are beginning to grow. Subsequently, goes the dynamic growth phase which is characterised by large demand, but when it reaches the 
specified maximum (the so-called upper turning point) the economic situation goes into the crisis phase again (Samuelson and Nordhaus 2004).

Table 2

Direction of the dynamics of prices in the global and domestic milk market

\begin{tabular}{lccc}
\hline \multirow{2}{*}{ Specification } & World prices & Milk market \\
\cline { 3 - 4 } & & Milk buying-in prices & $\begin{array}{c}\text { Selling prices of Polish } \\
\text { dairy products }\end{array}$ \\
\hline $2004-2005$ & $\Uparrow$ & $\downarrow$ & $\Uparrow$ \\
2006 & $\downarrow$ & $\Uparrow$ & $\downarrow$ \\
2007 & $\Uparrow$ & $\downarrow$ & $\Uparrow$ \\
2008 & $\Uparrow$ & $\downarrow$ & $\downarrow$ \\
2009 & $\downarrow$ & $\Uparrow$ & $\downarrow$ \\
$2010-2011$ & $\Uparrow$ & $\downarrow$ & $\uparrow$ \\
2012 & $\downarrow$ & $\Uparrow$ & $\uparrow$ \\
2013 & $\Uparrow$ & $\downarrow$ & $\downarrow$ \\
$2014-2015$ & $\downarrow$ & $\Uparrow$ & $\Uparrow$ \\
$2016-2017$ & $\Uparrow$ & & $\downarrow$
\end{tabular}

Source: own calculations, data from GUS, ARR, MF CAAC.

The dynamics of individual market elements, including prices, can be highly diversified. It is expressed by asymmetric price transmission among the markets separated in space. Analysis of the global and domestic milk market allowed to identify the duration of the business cycle in the dairy industry. Upward trends in prices persist mostly for two years, and then are followed by a two-year price fall. There are derogations from this rule and then the business cycle is shortened to annual periods (Fig. 2, Table 2). The main determinant of the business cycle fluctuations is the demand variability and the level of stocks of durable dairy products in the developing countries. Changes on the supply side are less important as the raw milk production in the world is increasing, on average, by $2 \%$ a year (OECD-FAO, 2016). An important role in this respect is also played by investment capital in commodity stock exchanges, which in the conditions of low interest rates is looking for the highest possible rates of return. Shortterm fluctuations are caused by fortuitous - climate or political - factors. Adverse weather conditions during the growing season (e.g. drought, hurricanes) or a tense situation in international relations (e.g. Russian embargo ${ }^{3}$ ) may result

\footnotetext{
${ }^{3}$ The Government of the Russian Federation, Regulation of 7 August 2014, No. 778, Moscow. on activities related to the implementation of the Decree issued by the President of the Russian Federation No. 560 of 6 August 2014. "On the use of certain special economic measures in order to guarantee security of the Russian Federation". Retrieved from: http:/government.ru/media/files/41d4f8cdfeeb731522d2. pdf (accessed on: 05.06.2017).
} 
in high price volatility during a year. Knowledge of the duration of the business cycle and its analysis allows all market participants in the milk market to prepare for upcoming changes in the supply-demand situation and, consequently, for the price situation. Economic entities may in advance prepare appropriate risk management instruments, and administration - more effective intervention instruments (the so-called safety net).

Statistical analysis also showed that prices at the individual stages of the domestic marketing chain in the dairy industry are characterised by volatility, but their dynamics was very different. In 2004-2016, the cumulative milk purchase price index amounted to $171 \%$, selling price index $-103 \%$, and retail price index $-132 \%$ (Fig. 3). Real purchase prices increased most, contrary to farmers' opinion that the dairy industry and retail take over the economic surplus, by using the stronger market position. It should be noted that the shape of the curve of purchase and selling prices is very similar and corresponds to business cycle fluctuations in the milk market. However, purchase prices were characterised by the greatest rises and falls, which substantially increased the risk of the economic activities and could lead to crisis situations on some farms. A relatively small rise in selling prices also results from the cooperative form of ownership of a large part of the dairy industry. Farmers are shareholders of dairy cooperatives, which in the first place follow the interests of their members. Therefore, in the economic activity it is very important to pay farmers high purchase prices while, to a smaller extent, to gain profit. Analysis of prices in the marketing chain clearly shows the strong position of retail trade. Retail prices were characterised by a low but stable dynamics and very low volatility. As a result, the risk of pursuing the economic activity was relatively small. In the periods of deep falls in purchase prices and small changes in retail prices, farms and the dairy industry pointed to the very strong market position of large retail chains. The disproportionate dynamics at the further stages of the chain clearly suggests that vertical price transmission shows asymmetry.

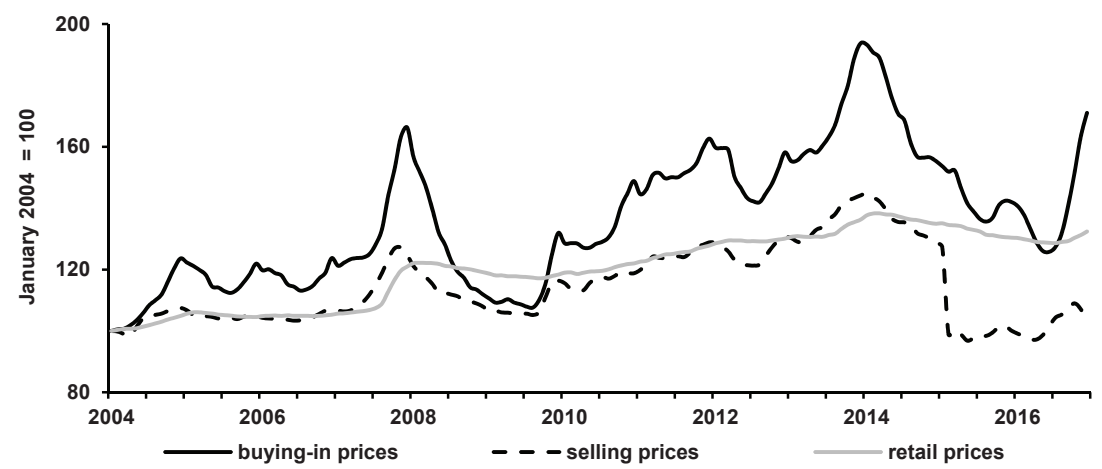

Fig. 3. Dynamics of prices in the domestic milk and dairy products market. Source: own study based on CSO unpublished data. 
The results of statistical ADF tests showed that stochastic processes of price indices were non-stationary and were brought to the stationary form, by using the first differences of the logarithms (Table 3). The directions of price signals in the marketing chain of the Polish dairy industry was analysed using the Granger causality tests at three stages: raw material base - processing (purchase prices $\rightarrow$ selling prices), processing - retail trade (selling prices $\rightarrow$ retail prices) and raw material base (purchase prices $\rightarrow$ retail prices) - retail trade. Price signals ran from purchase prices through processing to final product prices. The dynamics of prices at the individual stages was determined to a greater extent by supply-side factors. The demand for dairy products is not much flexible (Kwasek, 2013). The dairy industry is mostly of cooperative nature and shareholders are farmers. Cooperatives pay farmers relatively high purchase prices, instead of a profit dividend. Factors affecting price signals was also the economic situation in external markets and the agricultural policy (e.g. support for internal demand and farmers' income).

Table 3

Results of the ADF tests with absolute terms and price trend on the Polish milk market

\begin{tabular}{ccccc}
\hline Description & $\begin{array}{c}\text { Critical value } \\
\boldsymbol{\alpha}=\mathbf{1 - \sigma}\end{array}$ & $\begin{array}{c}\text { Dickey-Fuller } \\
\text { statistics }\end{array}$ & Value $\mathbf{p}$ & Decision \\
\hline Purchase prices & -0.057 & -3.014 & 0.316 & \\
Selling prices & -0.061 & -3.015 & 0.155 & \\
Retail prices & -0.039 & -3.073 & 0.112 & \\
\hline & Price indices, previous month $=\mathbf{1 0 0}$ & \\
\hline Purchase prices & -1.187 & -8.014 & $4.765 \mathrm{e}^{-17}$ & $I(1)$ \\
Selling prices & -1.103 & -9.236 & $1.015 \mathrm{e}^{-17}$ & $I(1)$ \\
Retail prices & -0.923 & -7.089 & $1.238 \mathrm{e}^{-11}$ & $I(1)$
\end{tabular}

Source: own calculations, unpublished GUS data.

Econometric analysis confirmed the presence of a cointegration relationship at the individual stages of the marketing chain in the dairy sector. The results of the empirical analysis using the error correction model (ECM) showed asymmetric price transmission, whose mechanism at the individual stages of the marketing chain were different. The coefficients $\alpha_{t-1}$ have negative signs and confirm the return of prices to the long-term balance after the price "shock". The largest asymmetry takes place between purchase prices of raw materials and retail prices of dairy products. Lower asymmetric price transmission was characteristic of the stage of distribution from the dairy industry to retail trade (Table 4). The results obtained from the error correction model correspond to the results of analysis of aggregate price indices. Purchase prices were characterised by noticeably greater variability than retail and selling prices. 
The results of the studies confirmed the very complex nature of the price transmission process, as it combines prices' adaptation to short- and long-term balance. As a result, the risk of the economic activity in agriculture and in the dairy industry is greater than in retail trade. For the detailed inclusion of the processes of adaptation to short-term balance, it is necessary to extend the studies using TAR or M-TAR models (Momentum Threshold Autoregressive Model) (Hamulczuk, 2011; Socha, 2014).

Table 4

Tests of asymmetric price transmission on the Polish milk market

\begin{tabular}{|c|c|c|c|c|c|c|c|c|c|}
\hline \multirow{2}{*}{$\begin{array}{l}\text { ECM model } \\
\text { parameters }\end{array}$} & \multicolumn{3}{|c|}{$\begin{array}{c}\text { Endogenous variable CD } \\
\text { Exogenous variable CS }\end{array}$} & \multicolumn{3}{|c|}{$\begin{array}{c}\text { Endogenous variable } \mathrm{CZ} \\
\text { Exogenous variable CS }\end{array}$} & \multicolumn{3}{|c|}{$\begin{array}{c}\text { Endogenous variable } \mathrm{CD} \\
\text { Exogenous variable } \mathrm{CZ}\end{array}$} \\
\hline & Coeff. & Stat. $t$ & $p$ & Coeff. & Stat. $t$ & $p$ & Coeff. & Stat. $t$ & $p$ \\
\hline$C$ & $5.24 \mathrm{e}^{-7}$ & 0.1670 & 0.9356 & $-1.02 \mathrm{e}^{-6}$ & -0.3033 & 0.8899 & $3.21 \mathrm{e}^{-7}$ & 0.0049 & 1.0120 \\
\hline$\gamma_{t-1}$ & 0.0612 & 1.3015 & 0.2001 & 0.1612 & 3.5012 & 0.0030 & 0.1334 & 3.2012 & 0.0014 \\
\hline$\gamma_{t-2}$ & -0.0011 & -0.3878 & 0.8025 & 0.0013 & 0.1433 & 0.9112 & 0.1012 & 1.9001 & 0.1609 \\
\hline$\gamma_{t-3}$ & 0.0023 & 1.2493 & 0.4003 & 0.0009 & 0.5409 & 0.7054 & 0.0199 & 2.6125 & 0.0133 \\
\hline$\alpha_{t-1-}$ & -0.3478 & -5.6243 & 0.0011 & -0.3455 & -5.0012 & 0.0001 & -0.4354 & -3.6904 & 0.0002 \\
\hline$\alpha_{t-1}^{+}$ & -0.6956 & -7.5344 & 0.0001 & -0.6754 & -3.7560 & 0.0006 & -0.7366 & -7.4375 & 0.0007 \\
\hline$\beta_{t-1}$ & -0.1456 & -1.1239 & 0.0307 & -0.4509 & -3.2012 & 0.0030 & -0.0424 & -0.7733 & 0.5024 \\
\hline$R^{2}$ & & 0.8324 & & & 0.7522 & & & 0.6388 & \\
\hline$D W$ & & 2.2123 & & & 2.1004 & & & 2.0412 & \\
\hline
\end{tabular}

Explanations: $\mathrm{CS}$ - purchase price, $\mathrm{CZ}$ - selling price, $\mathrm{CD}$ - retail price.

Source: own calculations, unpublished GUS data.

\section{Summary}

The dairy industry in Poland in the period of membership in the EU continued processes of adaptation to the ever-changing market conditions, including in particular changing market regulations. Sector entities carried out structural and modernisation transformations including, in particular, the concentration of subjective structures. In 2004-2016, there was an increase in the concentration of raw milk and dairy products production, but these processes are not yet completed.

Sector entities adapted to the ever-changing economic situation, including especially on the external market. On the Polish milk market, there is the surplus of supply and foreign trade is of great importance in the market balance. As a result, the domestic market is largely dependent on the price situation on foreign markets. The results of the studies showed that the directions of changes in milk 
purchase prices and dairy product selling prices in Poland were characterised by the similar directions of changes as global dairy products prices. The domestic market is cointegrated with the global market. The business cycle lasts, on average, 2 years, but there are some exceptions to this rule. Sector entities can, therefore, implement risk management instruments so as to wait through the downturn periods.

The milk market in the EU is one of the most regulated food markets, despite the liquidation of the supply management system (milk quotas) in 2015. The system of regulations still includes many instruments forming the safety net. An important element of market regulations is to empower farmers in the marketing chain by contracting agreements and a possibility of creating producer groups and inter-branch organisations.

Analysis of prices on the domestic milk market showed that despite market regulations, prices were characterised by high volatility (variability), including, in particular, milk purchase prices. The lowest volatility was shown by retail prices. Large differences in cumulative price indices on the milk market suggest asymmetric price transmission in the marketing chain. Changes in raw material prices did not result in symmetric changes in selling and retail prices of dairy products. Econometric analysis using the ECM model confirmed asymmetry of the price formation process. In addition, there were cointegration relationships in the supply chain as there are trends to restore long-term balance. A similar situation applies to cointegration with the global market, whose impact on the domestic market was very important. The results of the studies confirmed that the largest asymmetric price transmission occurs in the purchase prices/selling prices relationship. Large variability of purchase prices with relatively low changes in retail prices is an argument in favour of empowering farmers in the supply chain. However, we should remember about the very large impact of the global economic situation on the price situation on the domestic market.

Studies on asymmetric price transmission in the dairy industry should be continued in the future, and their objective should be the process of adaptation to short-term balance using the M-TAR and TAR models. 


\section{References}

Aczel, A.D. (2005). Statistics in management.Warsaw: PWN.

Aguiar, D.R.D., Santana J.A. (2002). Asymmetry in farm to retail price transmission: evidence from Brazil. Agribusiness, no. 18.

AMI. (2017). Markt Bilanz. Milch 2017, Agrarmarkt Iformations-Gesellschaft mbH, Bonn.

Azzam, A. (1999). Asymmetry and Rigidity in Farm-Retail Price Transmission. American Journal of Agricultural Economics, 81, pp. 525-533.

Ball, L., Mankiw, N.G. (1994). Asymmetric price adjustment and economics fluctuations. The Economic Journal, 104, pp. 246-252.

Benson, B.L., Faminow, M.D. (1985). An alternative view of pricing in retail food markets. American Journal of Agricultural Economics, no. 67.

Chavas, J.P., Metha, A. (2004). Price Dynamics in a vertical Sector: The Case of Butter. American Journal of Agricultural Economics, 86, pp. 1078-1093.

Council Regulation (EC) No. 1787/2003 of 29 September 2003 amending Regulation (EC) No. $1255 / 1999$ on the common organisation of the market in milk and milk products (L 270, 21.102003).

Conforti, P. (2004). Price transmission in selected agricultural markets. FAO Commodity and Trade Policy Research Working Papers, no. 7.

Czarny, E. (2002). Theory and practice of intra-industry trade. Monographs and Papers, SGH Warsaw School of Economics, no. 496. Warsaw: SGH Warsaw School of Economics.

Engle, R.F., Granger, C.W.J. (1987). Cointegration and error correction: Representation, estimation and testing. Econometrica, 49, pp. 251-276.

Hamulczuk, M. (2013). Asymmetric price transmission in the food chain. Example of prices of poultry in Poland. Research Papers of Wrocław University of Economics, 307 , pp. 212-223.

Hamulczuk, M. (2011). Forecasting prices of agricultural raw materials using time series models. Multi-annual Programme 2011-2014, no. 10. Warsaw: IERiGŻ-PIB.

Heien, D.M. (1980). Markup pricing in a dynamic model of food industry. American Journal of Agricultural Economics, No. 59.

Holm, T., Steinhagen, C., Loy, J-P. (2010). Preistransmissionen für Konsummilch und Butter in den verschiedenen Distributionskalälen des Lebensmittelhandels. Braunschweig, GEWISOLA.

Holst, C., von Cramon-Taubadel, S. (2012). Preistransmissionen entlang deutscher Wertschöpfungsketten für Nahrungsmittel. Breunschweig, GEWISOLA.

Houk, J.P. (1977). An Approach to Specifying and Estimating Nonreversible Functions. American Journal of Agricultural Economics, 59, pp. 570-572.

Granger, C.W.J., Lee, T.-H. (1989). Investigation of production, sales and inventory relationship using multicointegration and non-symmetric error correction models. Journal of Applied Econometrics, no. 4.

Kusideł, E. (2000). Vector autoregressive modelling VAR. Methodology and application in economic studies. Łódź: Absolwent.

Kwasek, M. (2013). Nutrition - level and diversification. In: Production and economic of the situation of agriculture and food economy in 2012. Warsaw: IERiGŻ-PIB. 
Luoma, A., Luoto, A., Taipala, M. (2004): Threshold cointegration and asymmetric price transmission in Finnish beef and pork market. Pellerevo Economic Research Institute, no. 70.

Łyszkiewicz, W. (2000). Industrial organization. Warsaw: WSKiFM.

McCorriston, S., Morgan, C.W., Rayner, A.J. (2001). Price transmission: the interaction between market power and returns to scale. European Review of Agricultural Economics, no. 2.

Meyer, J., von Carmon-Taubadel, S. (2004). Asymetrie Price Transmission: A Survey. Journal of Agricultural Economics, no. 55, pp. 581-611.

Mynarski, S. (1993). Market analysis - systems and mechanisms. Kraków.

OECD-FAO, (2016). OECD-FAO Agricultural Outlook 2016-2025. Retrieved from: http:// www.fao.org/3/a-i5778e.pdf, OECD/FAO, Paris.

Pelzmann, S. (2000). Proce rise faster than they fall. Journal of Political Economy, 108, pp. 466-502.

Pietrzak, M., (2006): Financial efficiency of dairy cooperatives - concept of assessment. Warsaw: Warsaw University of Life Sciences.

Pietrzak, M. (2014). Problem of the geographical scope of markets/sectors in the era of globalisation. Issues of Agricultural Economics, no. 1(338), pp. 3-21. Warsaw: IERiGŻ-PIB.

Porter, M.E. (2001). Porter on competition. Warsaw: Polish Economic Publishing House.

Regulation (EU) No. 1308/2013 of the European Parliament and of the Council of 17 December 2013 establishing a common organisation of the markets in agricultural products and repealing Council Regulations (EEC) No. 922/72, (EEC) No. 234/79, (EC) No. 1037/2001 and (EC) No. 1234/2007

Rembeza, J., Seremak-Bulge, J. (2006). Asymmetric price transmission in the milk and dairy products market. Issues of Agricultural Economics, no. 3(308), pp. 110-123. Warsaw, IERiGŻ-PIB.

Rembeza, J., Seremak-Bulge, J. (2010). Changes in prices and price relationships in basic food markets. Issues of Agricultural Economics, no. 1(322), pp. 112-125. Warsaw, IERiGŻ-PIB.

Rembeza, J., Seremak-Bulge, J. (2009). Evolution of basic agricultural markets and its impact on price transmission in the years 1990-2008. Multi-annual Programme 20052009, no. 131, Warsaw: IERiGŻ-PIB.

Rembisz, W., Kowalski, W. (2007). Agricultural market in functional terms. University of Finance and Management. Warsaw: IERiGŻ-PIB.

Milk market. State and prospects (2005-2017). No. 29-52. Warsaw: IERiGŻ-PIB, AMA, MARD.

Samuelson, P.A., Nordhaus, W.D. (2004). Economics. Warsaw: PWN.

Seremak-Bulge, J., Hryszko, K., Zalewski, A., (2006): Regional differentiation of the dairy industry. Communications Expert Opinions Reports, no. 520. Warsaw: IERiGŻ-PIB.

Seremak-Bulge, J., Szajner, P., Świetlik, K., Hryszko, K., Rembeza, J., Pieniążek, K. (2005). Development of the dairy market and changes in its functioning in the years 1990-2005. Multi-annual Programme 2005-2009, no. 21. Warsaw: IERiGŻ-PIB.

Socha, R. (2014). Asymmetry of the relationship of liquid fuel prices in Poland and oil prices. National Economy, no. 5(273), pp. 135-160.

Szajner, P. (2015). Price relationships in the Polish milk market after the accession to the EU. Research Papers of Wrocław University of Economics, no. 402, pp. 359-367. 
Szajner, P. (2009). Prospects of the export of Polish dairy products in the ever-changing conditions. Studies and Monographs, no. 146. Warsaw: IERiGŻ-PIB.

Sznajder, M. (1999). Economics of the Dairy Industry. Poznań: AR.

Szczepaniak, I., Ambroziak, Ł., Bednarz, J., Bułkowska, M., Kawecka-Wyrzykowska, E., Tereszczuk, M. (2015). Competitiveness of Polish food producers and its determinants (1). Multi-annual Programme 2015-2019, no. 11, Warsaw: IERiGŻ-PIB.

Szymański, W. (2002). Globalisation. Challenges and risks. Warsaw: Difin.

Takayama, T., Judge, G. (1971). Spatial and temporal price allocation models. Amsterdam: North-Holland Publishing.

Urban, R., (2004). Transformations of the food industry in the years 1988-2003. Studies and Monographs, no. 121. Warsaw: IERiGŻ-PIB.

Urban, R. (ed.). (2008). The impact of the EU integration on the Polish food economy. Multiannual Programme 2005-2009, no. 90. Warsaw: IERiGŻ-PIB.

Ward, R.W. (1982). Asymmetry in Retail, Wholesale, and Shipping Point Pricing for Fresh Vegetables. Marketing Since, no. 23, pp. 28-49.

Wrzosek, W. (2002). Functioning of the market. Warsaw: PWE.

Varian, H.R. (1997). Microeconomics. Warsaw: PWN.

Von Cramon-Taubadel, S. (1998). Estimating asymmetric price transmission with the error correction representation: An application to the German pork market. European Review of Agricultural Economics, no. 25. 
PIOTR SZAJNER

Instytut Ekonomiki Rolnictwa i Gospodarki Żywnościowej

- Państwowy Instytut Badawczy

Warszawa

\title{
TRANSMISJA CEN NA RYNKU MLEKA W POLSCE W LATACH 2004-2017
}

\begin{abstract}
Abstrakt
Polskie mleczarstwo dostosowało się do warunków członkowska w UE, gdzie rynek mleka należy do najbardziej uregulowanych rynków żywnościowych. Pomimo rozbudowanych regulacji rynkowych ceny mleka surowego i produktów mleczarskich $w$ Polsce charakteryzowały sie duża zmiennością. W szczególności dotyczy to cen skupu i cen zbytu. Na rynku mleka wystepuje nadwyżka podaży, która jest eksportowana. W związku z tym sytuacja cenowa $w$ kraju jest silnie uzalezniona od koniunktury na rynkach światowych. Ceny skupu i zbytu wykazują analogiczne kierunki zmian jak ceny światowe. Zmienność cen wystepuje także w krajowym łańcuchu marketingowym, gdyż ceny na jego poszczególnych etapach charakteryzuja sie bardzo zróżnicowana dynamika. Proces transmisji cen $w$ łańcuchu dostaw krajowego mleczarstwa wykazuje znaczna asymetrie. W zwiazku z tym zasadne sa instrumenty polityki rynkowej, które ograniczają ryzyko prowadzenia działalności gospodarczej oraz wzmacniają pozycje rolników $w$ relacjach z przemysłem mleczarskim i handlem detalicznym.
\end{abstract}

Słowa kluczowe: mleczarstwo, ceny, rynek, łańcuch marketingowy, transmisja cen. Accepted for print: 29.12.2017.

Unless stated otherwise all the materials on the website are available under the Creative Commons Attribution 3.0 Poland license. Some rights reserved to the Institute of Agricultural and Food Economics - National Research Institute.

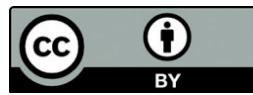

